\title{
THE INFLUENCE OF TOXIC EFFECTS OF ARSENOBENZOL COMPOUNDS ON THE WASSERMANN REACTION
}

By P. C. P. INGRAM, M.B., B.S.(Lond.), Hon. Physician for Diseases of the Skin, and M.O. in Charge V.D. Clinics, Royal Gwent Hospital, Newport, Mon.

THE behaviour of the Wassermann reaction in cases of syphilis who have developed jaundice or dermatitis under arsenobenzol treatment appears to be a matter of some interest, particularly as the amount of treatment required to effect a permanent cure is still a matter of some difference of opinion.

Little appears, so far, to have been written on the subject by British syphilologists. Dealing with toxic dermatitis only, Lees ${ }^{1}$ stated that if the blood serum be examined during an attack, the Wassermann reaction will generally be found to be negative, and it remains so in quite a percentage of cases for some time ; in others it may remain permanently negative. He quotes 3 cases which came under his notice in which the Wassermann reaction was temporarily made negative; two of these were cases of neuro-syphilis.

Franklin ${ }^{2}$ records fully 6 cases of dermatitis in all of which the Wassermann reaction became negative; he thinks that this is but a temporary change, and that, if no further treatment is given, it becomes positive again in six months.

In America, Cannon ${ }^{\mathbf{3}}$ has collected " fairly complete records " of $\mathrm{I} 35$ cases of jaundice, dermatitis and neuritis. Of these 38 per cent. became entirely negative, and I9 per cent. showed improvement. The majority were cases of jaundice; the stages of the disease are not mentioned, and only 22 of the patients had been followed up for periods of over three months, though some were observed for as long as twelve years. Cannon's conclusion is that some attacks are followed by results more favourable, even when the patient has not received what is usually regarded as a sufficient quantity of anti-syphilitic treatment to produce a negative Wassermann reaction and a clinical cure. 


\section{INFLUENCE OF TOXIC EFFECTS, ETC.}

Wile and Sams, ${ }^{4}$ in a recent paper reporting on 56 cases of jaundice in patients treated with arsphenamine, state that the blood findings are not constant or characteristic.

Kiel, reviewing the Continental literature in Jadassohn's Handbuch, ${ }^{\mathbf{5}}$ concludes that dermatitis per se only occasionally has a favourable effect on the Wassermann reaction and that a definite conclusion on the subject cannot be drawn.

In view of the division of opinion on the subject, it occurred to me that it might be interesting to see how the patients in the clinic under my charge had fared, and the records of male cases for a period of ten years have been examined.

During this time I24 cases were noted as having developed jaundice or dermatitis, and 73 of these were observed for a period of six months or over after the attack ; the results are shown in Tables I. and II. :-

\section{TABLE I}

Wassermann Reactions in 57 Cases of Jaundice developing under Arsenobenzol Treatment at the Onset of Symptoms, on Recovery and Later.

\begin{tabular}{|c|c|c|c|c|}
\hline $\begin{array}{l}\text { Stage of Syphilis and average } \\
\text { amount of "gi4" or equivalent } \\
\text { administered. }\end{array}$ & No. of cases. & $\begin{array}{l}\text { At onset of } \\
\text { symptoms. }\end{array}$ & On recovery. & Later. \\
\hline Primary, 4.92 gm. & $\begin{array}{r}\text { I7 } \\
2 \\
\text { I } \\
\text { I } \\
\text { I } \\
\text { I }\end{array}$ & $\begin{array}{l}\overline{-} \\
+- \\
++ \\
\overline{+}- \\
+-\end{array}$ & $\begin{array}{c}-- \\
\overline{-}- \\
\overline{-}- \\
\text { Not taken } \\
\text { Not taken }\end{array}$ & $\begin{array}{l}-- \\
-- \\
-- \\
++ \\
++ \\
+-\end{array}$ \\
\hline $\begin{array}{l}\text { Secondary, } \\
5 \cdot 31 \text { gm. . }\end{array}$ & $\begin{array}{l}4 \\
\text { I } \\
\text { I } \\
2\end{array}$ & $\begin{array}{l}-\overline{+} \\
+-\bar{t} \\
++\end{array}$ & $\begin{array}{l}-- \\
-- \\
--\end{array}$ & $\begin{array}{l}-- \\
-- \\
+-\end{array}$ \\
\hline Tertiary, $4.8 \mathrm{I}$ gm.. & $\begin{array}{r}0 \\
2 \\
\text { I9 } \\
3 \\
\text { I } \\
\text { I }\end{array}$ & $\begin{array}{l}++ \\
++ \\
++ \\
+- \\
\pm \\
--\end{array}$ & $\begin{array}{l}-- \\
-\overline{-} \\
++ \\
+- \\
\pm \\
--\end{array}$ & $\begin{array}{l}-\overline{+} \\
++ \\
++ \\
++ \\
\pm \\
--\end{array}$ \\
\hline Congenital, $3 \cdot 6 \mathrm{gm}$. & I & $+\underset{(\mathrm{Aft}}{+}$ & $\begin{array}{l}++ \\
\text { urther tre }\end{array}$ & $\frac{-}{\text { lent) }}$ \\
\hline
\end{tabular}


TABLE II

I4 Cases of Dermatitis

\begin{tabular}{|c|c|c|c|c|}
\hline $\begin{array}{l}\text { Stage of Syphilis and average } \\
\text { amount of "9r4" or equivalent } \\
\text { administered. }\end{array}$ & No. of cases. & $\begin{array}{l}\text { At onset of } \\
\text { symptoms. }\end{array}$ & On recovery. & Later. \\
\hline Primary', $7 \cdot 4$ gm. . & $\begin{array}{l}\text { I } \\
\text { I } \\
\text { I } \\
\text { I } \\
\text { I }\end{array}$ & $\begin{array}{c}-\overline{+} \\
\pm- \\
-\overline{-} \\
\pm\end{array}$ & $\begin{array}{l}-- \\
-- \\
+- \\
++\end{array}$ & $\begin{array}{l}-- \\
\overline{+}+ \\
\frac{-}{+}\end{array}$ \\
\hline Secondary, 6.25 gm. & 2 & -- & -- & -- \\
\hline Tertiary, 4.54 gm. & $\begin{array}{l}5 \\
\text { I } \\
\text { I }\end{array}$ & $\begin{array}{l}++ \\
+- \\
--\end{array}$ & $\begin{array}{l}++ \\
+\frac{1}{+}\end{array}$ & $\begin{array}{l}++ \\
+\frac{1}{+}\end{array}$ \\
\hline
\end{tabular}

* After further treatment.

So that of 36 cases of early syphilis, in 24 the serum reaction had already become negative at the onset of symptoms and remained so ; in 5 it improved to negative during the attack and remained so; in 3 it relapsed during the attack and improved only with further treatment; and in 4 it improved after the attack but relapsed later. Of 32 cases of late syphilis, in 29 the reaction was unchanged; in I it became worse ; and in 2 it improved but relapsed later.

Of the 5I cases who were not observed for more than six months after the attack, only I case of jaundice, in secondary syphilis, showed any improvement, the reaction changing from positive to doubtful, and I case of dermatitis, in primary syphilis, improved from doubtful to negative.

The results seem to show that the stage of syphilis under treatment had far-more to do with the change in the Wassermann reaction than had the occurrence of toxic jaundice or dermatitis, and that, although it may be tempting to surmise that the fact of the patient having had more than the maximum dose he could tolerate would favour a reversal of the serological reaction, there is little evidence of even a temporary improvement in this respect, as Wile and Sams have found. 


\section{INFLUENCE OF TOXIC EFFECTS, ETC.}

I am indebted to Mr. Spencer, one of the male nurses in my clinic for help in analysing the records.

\section{REFERENCES}

(I) LEes, D.: "Exfoliative Dermatitis following Arsenobenzol." Brit. Jour. Dermat. and Syph., I922, XXIV., 339.

(2) Franklin, J. L. : "Salvarsan Dermatitis." Brit. Jour. Dermat. and Syph., I930, XIII., I75.

(3) Cannon, A. B.: "A Study of the Wassermann Reaction following Dermatitis and Jaundice from Arsphenamine." Amer. Jour. Syph., I930, XIV., roo.

(4) WILE, U. J., and SAMS, W. M. : “A Study of Jaundice in Syphilis." Amer. Jour. Med. Sci., I934, CLXXXVII., 297.

(5) KIEL, W.: "Schadigungen durch Salvarsan." Jadassohn's Handbuch der Haut und Geschlechtskrankheiten, I928, XVIII., 634. 